\title{
Farmers-Herders Conflict and Nigeria's Quest for Food Security: The Imperative Need for Information Communications Technology
}

\author{
Olawale Olufemi AKINRINDE ${ }^{1(\varpi)}$ \\ ${ }^{1}$ Osun State University, Nigeria \\ olawale.akinrinde@uniosun.edu.ng \\ Abdullahi Abdullazeez OSUWA ${ }^{2}$ \\ ${ }^{2}$ Kogi State University, Nigeria \\ Kayode Wakili OLAWOYIN ${ }^{3}$ \\ Dauda Ayodele MORAKINYO ${ }^{4}$ \\ ${ }^{3,4}$ Osun State University, Nigeria
}

\begin{abstract}
Although Nigeria is best known for its oil and gas production, agriculture employs roughly $70 \%$ of its workforce. Nigeria has experienced a severe farmer-herder conflict that has negatively influenced its agricultural production capacity, resulting in severe food insecurity. Tensions have risen in recent decades, with increasingly violent clashes between farmers and herdsmen sweeping the country. In recent times, many scholarly studies and inquiries into the impact of information and communication technologies, particularly with respect to promoting food security in Nigeria, have been engendered mainly by the need to ensure greater agricultural outputs among farmers and other agriculturists. However, only scant attention has been devoted to understanding the imperativeness of the use of information communications technology in the quest to proffer solutions to the incessant farmers-herdsmen conflicts that have also contributed to the unpalatable state of food security in Nigeria. The study adopts Karl Marx's Conflict Theory as a framework of analysis and elicits qualitative data through content analysis of desktop data. Hinging on this theory, this study contends that the farmer-herdsmen conflict is inevitable, like every other conflict, due to the competition for limited land resources. On the other hand, the study discovered that the failure of relevant stakeholders to leverage the capabilities of information and communications technology to address the technological gap in the conflict is one of the reasons why the farmers-herdsmen conflict has persisted, among many other factors. While further findings suggest
\end{abstract}


Journal of Digital Food, Energy \& Water Systems, 2 (2): 33-54, 2021

ISSN 2709-4529

(C) Centre for Cyber Physical Food, Energy \& Water Systems

\begin{abstract}
that the principal causes and aggravating factors behind the escalating conflict are climatic changes, population growth, technological and economic changes, crime, political and ethnic strife, and cultural changes, the lack of the use of information and communications technology in the areas of educating both the farmers and herders, awareness creation, crime reporting, and conflict resolution further compounds the farmer-herdsman conflict. This study advocate for the proper and improved use of I.C.T. in the processes of resolving farmer-herdsmen conflicts.
\end{abstract}

\title{
Keywords-Farmers-herdsmen, Conflict, Food Insecurity, Information and Communications Technology, Nigeria.
}

\section{Introduction}

Centuries ago, roving herders habitually moved across the northern regions of modern Nigeria for grazing. However, the damage of outdated grazing lands to desertification, drought, and conversion to farmland has forced many pastoralists to rove south into sedentary farming communities or agricultural populations. The herders' movement had always been formerly seasonal, spending the dry season in central Nigeria, where there is more grazing land available for the herders, while returning back to the core north as soon as the rainy season begins. As more of northern Nigeria becomes desert, with grasses shrinking, basically, on a permanent basis, herders have chosen to wander to the south, searching for more fecund grazing land. Frequently, more than often, it resulted in clashes with farmers across Nigeria for access to land and water. Farmers frequently accuse herders of trespassing on their land, while herders frequently blame farmers or members of their host community for livestock thievery [1].

Anter [2] posits accordingly that the Fulanis have traditionally been nomadic pastoralists, following people and herding cattle, sheep, and goats over their vast desert hinterlands, keeping themselves somewhat apart from the main agricultural population. Their origins are disputed, with some researchers claiming Judaea-Syrian ancestry and others claiming a North African origin. From the Tekruur Kingdom in today's Senegal area, the clan has migrated from the Middle East through North Africa and established itself in Central and West Africa [3]. The world's largest nomadic community is said to be Nigerian herders. While most of them remain semi-nomadic herders in Nigeria, others have embraced modernity and moved to the cities. Nomadic tribes, in contrast to more integrated city dwellers, spend the majority of their time in the bush and are frequently involved in the herder-farmer conflict. These herders regularly conflict with 
Journal of Digital Food, Energy \& Water Systems, 2 (2): 33-54, 2021

ISSN 2709-4529

(C) Centre for Cyber Physical Food, Energy \& Water Systems

agricultural communities as they herd the animals across huge distances. The problem is exacerbated by the fact that grazing reserves have been transformed into cropland, while traditional grazing paths have been obstructed by urban growth. While this conflict is essentially over land, it is becoming increasingly political along religious and ethnic lines. The herders are largely Fulani in ethnicity and practice Islam, but the majority of sedentary farmers are Christians [4]. Several participants in the herderfarmer disputes use religion to explain their acts. Although climate change and religious tensions have played a role in the rise of this conflict between herders and farmers, the lack of an effective institution and intervention capable of resolving differences and the readily available guns has caused disagreements to turn violent. The government's response to the clash includes deploying security troops to the affected areas and forming a command to look for a feasible way out. However, because of corruption and a lack of funds, its reaction has been ineffective in quelling the violence. The government's failure to provide security for local inhabitants and prosecute violent culprits has resulted in the establishment of militias equipped with machetes and modern weaponry to protect themselves against further assaults. This has exacerbated the problem. A high number of clashes have erupted between farmers and herders in Benue State, in north-central Nigeria. Because of its fecundity, the state has been dubbed the "Food Basket of the Nation," and its population and demand for agriculture have skyrocketed [5]. As a result, grazing grasslands have been converted to agriculture, and grazing routes have been blocked at a time when a growing number of herders are flocking to the region. In reaction to the closure of their traditional grazing sites, herders bring their cattle to graze on farmers' crops, causing damage to cultivated fields. Currently, the expedition to boost food security in the country is endangered by conflicts that have become tantamount not only with Nigeria but also with most West African countries. Competition over land resources has become a common manifestation between farmers and herdsmen in every part of Nigeria.

The turmoil in the Middle Belt area has expanded to other sections of the country. It has appeared in the Nigerian states such as Rivers, Enugu, Ekiti, Oyo, Ogun, Edo, Ondo, Plateau, Nasarawa, Kaduna, and Benue [6]. In Benue State, there have been harrowing clashes that have taken many lives and properties in areas including Agatu, Guma, Gwer West, Makurdi, Kwande, Katsina-ala, and Logo. Conflicts in Benue State claimed the lives of almost 5,000 people between 2014 and 2017 [7]. It has sacked over 100 towns and driven thousands of refugees into IDP camps in Makurdi, Benue's capital city. These losses have had a negative impact on farming activities as well as other related businesses and socioeconomic activities, resulting in food insecurity across the country. Because of the fear of herdsmen's attack, most farmers in the conflict's hotspots have already abandoned farms. Farming is no longer a way of life for most farmers in 
Journal of Digital Food, Energy \& Water Systems, 2 (2): 33-54, 2021

ISSN 2709-4529

(C) Centre for Cyber Physical Food, Energy \& Water Systems

Benue and other affected states. Several farmers have been uprooted and evicted from their lands by armed individuals suspected of being herdsmen [8].

As farmers flee their farms for the safety of internally displaced person camps, their crops are being grazed upon, and their seedlings are used as cattle feed, which may prevent farmers from replanting even if they could return to their farms. Agricultural and development specialists agree that the achievements documented in the agricultural sector of the economy, particularly in food production, may suffer a significant setback due to the detrimental impacts of conflict between farmers and herders across the country. Balogun [9] revealed in his study of the causes and consequences of perennial clashes between herdsmen and farmers in Nigeria that the attacks have a significant impact on food security and have resulted in a $\$ 14$ billion loss in three years. Other economic consequences of these skirmishes include hampered trade practices, reduced crop yield, farmer relocation, loss of life and property, loss of items in storage, and damage to public and private facilities, in addition to severely delaying the country's economic development. Herder-farmer clashes are expected to continue to jeopardize Nigerian food security unless farmers and herders can reach an agreement using I.C.T to develop alternatives to the never-ending fight for land resources. According to Nyong and Fiki [10], resource-related conflicts are responsible for a more than 12\% reduction in per capita food output in Sub-Saharan Africa. Herdsmen have maintained a symbiotic relationship with local farmers for many decades before to Nigeria's independence, with fewer schisms. However, the relationship has deteriorated in recent years, resulting in the murders and the destruction of property [11]. According to Balogun [12], food security is a critical component of human security. By extension, if one component is harmed, the others are also harmed. The United Nations Food and Agricultural Organization (FAO) outlines four pillars of food security: availability, access, use, and stability [13]. Nonetheless, present realities have exposed a disconnect between the application of I.C.T. and food security and the settlement of farmersherdsmen confrontations. Herders and pastoralists in the most technologically sophisticated nations have reached new heights in ranching their herds, feeding, raising, and producing using technology.

However, in Nigeria, most herders are not even aware of the presence and the imperative for using information and communication technologies in the production and rearing of their cattle. Similarly, many farmers across the country are still oblivious to the possibilities embedded in the use of I.C.T. (Information Communications Technology) in the production, marketing, and preservation of their crops and farmlands. This explains why I.C.T use among the herders and farmers remains minimal. As a result, the purpose of this paper is to highlight the implications of the herders-farmers, conflict on food security in Nigeria, and the importance of I.C.T. in 
Journal of Digital Food, Energy \& Water Systems, 2 (2): 33-54, 2021

ISSN 2709-4529

(C) Centre for Cyber Physical Food, Energy \& Water Systems

achieving enhanced food security and reducing the occurrence farmers-herdsmen conflict.

\subsection{Conceptual Explication}

\section{a. Food Security}

Food is a necessity for humans. Man is thought to be incomplete without nourishment. According to Balogun [14], food has definite values that make it necessary to man. Food has biological, social, economic, and political implications for humans. During the 1974 World Food Conference, the term "food security" was coined to emphasize supply. Food security is thus defined as "the availability of sufficient world food supply of fundamental commodities at all times to enable stable growth in food consumption while offsetting the volatility in production and pricing" [15]. Demand and access concerns were added to advanced definitions of food security understanding. Food security "occurs when all people have physical and economic access to enough, safe, and nutritious dietary to fulfill their nutritional needs and food preferences for an active and healthy life at all times," according to the World Food Summit's closing report [16]. Food security is described as a state where everyone has enough food to live a healthy and productive life [17]. According to the Bureau for Africa, food security is defined as "a condition in which all people have physical, social, and economic access to adequate food to meet their dietary needs for a productive and healthy life at all times" [18]. The Food and Agricultural Organization of the United Nations (FAO) defined four food security supports: availability, accessibility, utilization, and stability [19]. The right to food was recognized by the United Nations (UN) in the 1948 Declaration of Human Rights [20], and it has since been emphasised that it is necessary for the enjoyment of all other rights [21]. Food insecurity is diametrically opposed to food security. FAO [22] defines food insecurity as a state in which individuals do not have secure access to adequate amounts of safe and nutritious food for normal growth and development, as well as an active and healthy life. It might be caused by a lack of food, insufficient purchasing capacity, incorrect distribution, or insufficient food utilization at the home level. The main reasons for low nutritional status include food instability, poor health and sanitation conditions, and inadequate care and feeding habits. Food insecurity can be long-term, seasonal, or transient. According to Balogun [23], food insecurity is a condition in which people do not have consistent physical or economic access to enough safe, nutritious, and socially acceptable food to live a healthy and productive life. According to the FAO, the leading causes of food insecurity include war, civil unrest, corruption, national policies that do 
Journal of Digital Food, Energy \& Water Systems, 2 (2): 33-54, 2021

ISSN 2709-4529

(C) Centre for Cyber Physical Food, Energy \& Water Systems

not encourage fair access to food for everyone, environmental degradation, inadequate agricultural development, and crop pests and diseases [24].

\section{b. Herdsmen}

Domestic animals such as cattle, sheep, goats, and so on are raised by herders. They are also known as "cattle breeders" or "cattle rearers," and they often live a nomadic existence while searching for grazing places for their animals with sticks and cutlasses in their hands. The Fulani is the world's biggest semi-nomadic group, and they may be found from Senegal to the Central African Republic [25]. Some live as semi-nomadic herders in Nigeria, while others have settled in towns. According to Nwosu [26], the Fulani is sometimes lumped in with the Hausa ethnic group (thus the designation, Hausa-Fulani), despite the fact that both ethnicities are separate. In Nigeria, the Many Fulani are nomadic herders; however, some live in established areas. Because of the nature of their livelihood, they leave their base in northern Nigeria in search of greenery for their cattle in southern Nigeria. As Aluko [27] points out, the interaction of widely scattered Fulani with other communities has resulted in diverse socioeconomic patterns.

\section{c. Farmers}

A farmer cultivates the soil or raises livestock for food and raw materials. Crop farmers, poultry farmers, animal breeders, and other sorts of farmers exist. Although crop farmers and Fulani herders both work in agriculture, crop farmers may also be referred to as stockbreeders. Among the Fulani herders, some individuals practice mixed farming. This demonstrates the connections between farming and herding as a vocation in agriculture. The majority of farmers in Nigeria come from communities in the North Central and Southern regions. Farmers grow a variety of food crops, including yams, rice, maize, guinea-corn, millet, soya beans, cassava, groundnut, cotton, Irish potatoes, sweet potatoes, tomatoes, onions, cabbage, and carrots [28].

\section{d. Conflicts}

Conflicts are common in human social connections and are essential components of social life. They are commonly characterized as a dispute between two or more individuals over irreconcilable aims. They happen between people, social units, and groupings. According to Adisa [29], conflict is a persistent aspect of human social relationships. In other words, conflict is unavoidable in human social interaction due to people with a community's perception of insufficient resources. According to Albert [30], conflict is defined as an antagonism among the social units directed against one another.

Furthermore, Albert [31] defines conflict as a connection between two or more people that are seen to have opposing agendas. Albert [32] defines conflict as a situation 
Journal of Digital Food, Energy \& Water Systems, 2 (2): 33-54, 2021

ISSN 2709-4529

(C) Centre for Cyber Physical Food, Energy \& Water Systems

in which there is insufficient or no compromise amongst social units. Personal or interpersonal conflict, intragroup or intergroup conflict, and so on. This study focuses on the intergroup conflict between farmers and herders.

\section{Theoretical Explications}

There are several theoretical hypotheses for the reasons and character of the Nigerian herder-farmer conflict. The disagreement is best characterized using social conflict theory. As a result, it has been adopted as a frame of analysis here. Social conflict theories highlight the importance of conflict in determining social circumstances and the dynamics of social life. In reality, when we study and engage in social life, we frequently come into conflicts or possible conflictual conditions among people, social groupings, political parties, and so on.

The concept considers social existence a struggle and focuses on the distribution of scarce resources and power, which are not distributed evenly by nature. Proponents of this theory see society as a collection of people with diverse demands and interests who have limited resources to meet those demands. Inequality ensues, resulting in social strife and, eventually, social transformation. Karl Marx is widely acknowledged as the father of social conflict theory. According to social conflict theory, conflicts for power and control in society are a major source of conflict. Conflict occurs when two or more actors oppose each other in social interaction, using social forces reciprocals in an attempt to achieve scarce or incompatible goals while preventing the opponent from attaining them. Instead of reaching an agreement, the desire for supremacy and power becomes the currency. The theory's central idea is that society is constantly competing for finite resources. This captures the rationale as to why the farmers and herders are often locked in an incessant struggle over equally desired resources. Whilst the farmers often regard farmlands as sacrosanct and imperative to their subsistence and livelihood, the herders consider the farmlands as a critical imperative for the survival of their cattle. This has always prompted a contest between these two social groups.

Again, in this case, the inadequate resources are lands, and the battle over land resources has always informed the farmers-herdsmen skirmishes in Nigeria. Even though the confrontations have taken on political, religious, and ethnic aspects, administrations at the local, state, and federal levels have been unable to resolve the competing interests between herders and farmers or aid them in reaching a solution. Regardless, the social conflict theory affords us the opportunity to understand the 'why' of the conflict. 
Journal of Digital Food, Energy \& Water Systems, 2 (2): 33-54, 2021

ISSN 2709-4529

(C) Centre for Cyber Physical Food, Energy \& Water Systems

\section{Thematic and Content Analysis of Findings}

\subsection{Farmers-Herders Conflict in Nigeria: Dynamics and Causes}

Nigeria emphasizes promoting agriculture as a viable alternative to oil as a key national wealth foundation. Many individuals are going into farming, and more people are getting into livestock, including cow breeding. Attacks and retaliation by farmers and herders result in the annihilation of lives and property. According to Bello [33], attacks by Fulani herdsmen in Nigeria killed 3,780 Nigerians across the nation, omitting the injured and abducted. On the other side, farmers have slaughtered dozens of cows and Fulani ranchers in retaliation for the annihilation of farms and agricultural produce by cows. The current herdsmen drive and subsequent clashes with farmers and host towns have increased insecurity in Nigeria, particularly in the North Central region and, by extension, throughout the country. The motivation for the clashes is competition for available resources, particularly grazing land. The competition for available resources, particularly grazing areas, is the motivation behind the confrontations. As a result, grazing reserves in a neglected agricultural area were unable to be maintained. It received little or no attention from successive governments. Herders returned to their traditional and seasonal grazing routes, which had been disrupted or hampered by industry, urbanisation, demography, and other natural forces, as a last resort. As a result, clashes and violence erupted between farmers and host communities. These conflicts have become increasingly common in recent years, and they now pose one of the most serious threats to Nigeria's national security [35]. To address these issues, the federal government established a Strategic Action Committee in June 2015 to investigate the problem and make recommendations to help the government deal with it. The Miyetti Allah Cattle Breeders Association (MACBAN), a key partner in this project, determined that climate change and desertification were major contributors to annual trans-human migration from the North to the South [36]. Because climate change and other linked variables are beyond the ability of farmers or herders to solve, active efforts by the government, business sector, regional authorities, and the global community are required to address these concerns. The need to resolve the problem is even more pressing since the conflicts threaten food and agricultural security and the country's unity, peaceful cohabitation, and harmony. Climate change (frequent droughts and desertification), population growth (loss of northern grazing lands due to human settlement expansion), technological and economic changes (new livestock and farming practises), crime (rural banditry and cattle rustling), political and ethnic strife (intensified by the spread of illicit firearms), and cultural changes ((the collapse of 
Journal of Digital Food, Energy \& Water Systems, 2 (2): 33-54, 2021

ISSN 2709-4529

(C) Centre for Cyber Physical Food, Energy \& Water Systems

traditional conflict management mechanisms), a dysfunctional legal regime that has endorsed crime to go unpunished and, consequently, has encouraged both farmers and herders to take laws into their own hands, as instant triggers of the incessant farmersherders skirmishes.

\section{a. Climate Change}

Climate is a chief key in herdsmen's and farmers' operations. The changing climatic circumstances, colloquially known as global warming, are undoubtedly having an impact on the survival of herders and farmers' companies. The Saharan desert encroachment on the Sahel area and other associated climatic variables have continued to impact herdsmen's livelihoods as they push further south in search of sufficient land, pitting them against farmers and host communities [37]. This worldwide phenomenon is now affecting various world regions, with ramifications, such as the herdsmen-farmer conflict.

\section{b. Depleting Farm Lands}

Constant urbanization and demographic upheavals in the modern world have increased farmers' proclivity to go further away from farming operations. Nigeria had a population of roughly 35 million people when it gained independence in 1960 [38]. However, 58 years later, it has risen to over 180 million individuals, with the trend anticipated to continue in the foreseeable future [39]. A population rise of this scale entails a corresponding increase in the demand for food goods as a basic human requirement. This also means that farmers will be more aggressive in their search for farmland. On the other hand, industrialization and urbanization have eroded available land, leaving little or nothing for farmers' subsistence. Herdsmen have been pitted against farmers as they migrate south in search of pasture for their animals, resulting in conflict and destruction. Agriculture along the Benue River, for example, produces over 20,000 tonnes of grain per year [40]. Herdsmen can feed their cattle in this same area, which is also fertile. As a result, the movement of the herdsmen has the greatest impact on farmlands along the river's edge, resulting in a number of clashes.

\section{c. Inattentive of Political Will}

The administration at all levels has proved a near-complete lack of the necessary political will in propositioning of a long-term reaction to the challenging demands of many contributors in the ongoing conflict between herders and farmers [41]. Political leaders have failed to enact proper laws accompanied by action to specify norms and boundaries for conflict parties. At the regional level, the Economic Community of West African States (ECOWAS) has a Trans-Human Movement Protocol, but the framework has yet to be fully implemented at the state level. A lack of political will among member 
Journal of Digital Food, Energy \& Water Systems, 2 (2): 33-54, 2021

ISSN 2709-4529

(C) Centre for Cyber Physical Food, Energy \& Water Systems

countries remains a roadblock. The lack of political will in Nigeria to implement this protocol and other frameworks such as the national ranching policy (which has been implemented in industrialized countries such as the Netherlands, Argentina, and others) contributes to the failures to control the schisms. An attempt has been made in the time past by the federal government to regulate and control pastoral activities, but it appears that appropriate political will is required to carry out some of its policies. For example, the government is sympathetic to the herdsmen's activities in some quarters, particularly by opposition parties [42]. This sharpness is most likely due to the fact that the President is Fulani, the ethnic group that controls the cattle industry. Citizens, particularly those from the worst-affected states, had expected the government to deal decisively with recalcitrant herdsmen-farmers conflicts across the state with the same zeal and determination as it had shown in dealing with similar internal security issues such as separatist movements in the country's eastern and western regions. The scourge of farmers-herdsmen, on the other hand, continues to be a recurring decimal in the country.

The fact that the President is Fulani, the same ethnic group that controls the cattle trade, is most likely to blame for the uproar. Citizens, particularly in the worst-affected states, expected the government to deal decisively with recalcitrant herdsmen-farmers conflicts across the state with the same zeal and determination it displayed in dealing with similar internal security issues like separatist movements in the country's east and west. On the other hand, the plague of farmers-herders is still a recurring theme.

\subsection{The Farmers-Herders Conflict Implications/Consequences on Food Security in Nigeria}

The majority of Nigeria's population lives in rural regions. Because agriculture is the primary concern of the rural people, communal violence or disputes have major ramifications for food supply and availability. The major economic activity of the inhabitants is crop agriculture and livestock keeping. As a result, communal conflicts have major consequences for the food chain. Warring tribes or groups frequently use manipulation to get access to food and cattle. As a result, food insecurity has become a side consequence of communal strife [43]. Communal strife is linked to food insecurity and, in most cases, reduces cash crop and livestock productivity and revenue. This decrease in output and revenue has major consequences for food security, potentially weakening the coping ability of individuals who rely on food resources for a living. The Fulani herders are undeniably important contributors to Nigeria's economy. They are the primary cattle breeders, meat producers, and the most readily available and 
Journal of Digital Food, Energy \& Water Systems, 2 (2): 33-54, 2021

ISSN 2709-4529

(C) Centre for Cyber Physical Food, Energy \& Water Systems

affordable source of animal proteins for Nigerians. The Fulani own over $90 \%$ of the cattle population in the country, accounting for one-third of agricultural GDP and 3.2 percent of total GDP [44]. The Fulani also significantly impacts the local food system and national food security. Furthermore, Abughdyer [45] reported that between 2010 and 2014, farmers and herdsmen crises in Benue state damaged 664.4 hectares (56.4 percent) of farmland in the three local governments of Agatu, Guma, and Logo. This poses a significant risk to food production in Nigeria, as the state is the country's food security focal point. The conflict's attendant consequences can also be seen within the prism of human, societal, economic, and security effects. In general, farmer-herder disputes have tremendous humanitarian consequences. The conflict between locals and nomads usually ends in death, population displacement, human harm, and loss of livelihood [46]. In this aspect, violence is capable of not only murdering people but also of rendering them homeless, displaced, and poor. In addition to the deaths by nomads and retaliation assaults by indigenous peoples, some people have become widows, widowers, orphans as a result of the hostilities, while other victims have been crippled or disabled. As a result of the violence, people become internally displaced, particularly women, who opt not to travel to the remote farm for fear of being attacked by nomads [47].

Citing the case of the Southern Kaduna between 1999 and 2017, no less than eightyfive (85) assaults were conducted, killing about one thousand three hundred and thirteen $(1,131)$ individuals and badly injuring sixty-nine (69) [48]. Many houses were set on fire, and many properties were damaged. In a nutshell, farmer-herder disputes result in the death of farmers, the destruction of their homes and assets, and the displacement of farmers. According to Alli [49], the social consequences of farmer-pastoralist conflict endangers peace and serenity among diverse communities. In their work on herdsmenfarmers disputes, Okoli and Atelhe [50] argued that such clashes frequently produce stressful and volatile inter-group connections among the various communities. There is currently a strong manifestation of mutual mistrust and enmity between host communities and Fulani herders. As a result, the herders regard the natives as enemies to their collective survival, and they believe that the conflict fosters mutual suspicion and perpetual tension, endangering peaceful coexistence, security, and the stability of society [51]. Threats and intimidation have also resulted from the conflict, forcing both farmers and herders to flee their conflict-prone settlements. The fearful relationship impacts the level of cooperation, agricultural activities, and economic exchanges between the two groups in this regard. 
Journal of Digital Food, Energy \& Water Systems, 2 (2): 33-54, 2021

ISSN 2709-4529

(C) Centre for Cyber Physical Food, Energy \& Water Systems

\subsection{A Review of Government's Strategic Response to the Herdsmen-Farmers' Conflict in Nigeria}

\subsubsection{Establishment of Grazing Reserves in $\mathbf{1 9 6 5}$}

In 1965, the northern regional administration launched one of the country's first initiatives to address the herdsmen-farmer dispute [52]. The grazing reserves designated huge land areas for herders to raise their cattle on. On the other hand, the grazing reserve system was not well supported. Before natural processes such as population growth and other associated repercussions such as urbanization and migration encroached on these designated regions, the government was still working on laws to legalize the grazing reserves, reducing herder chances of accessing the reserves.

\subsubsection{The Establishment of National Commission for Nomadic Education (NCNE) in 1989}

The Nigerian legal system backs the NCNE, which the federal government founded in 1989. The program's main goal was to help nomadic pastoralists integrate into society by providing them with mobile basic education and skill training. The program aims to integrate them into society through education.

\subsubsection{The Armed Forces deployment to Curb Internal Security}

The participation of the Nigerian Armed Forces, as provided in the Constitutional mechanism, is one of the federal government's urgent actions to handle farmersherdsmen disputes [53]. For example, in Plateau state, the government established (STF-OSH) Operation Safe Haven in 2001 to combat the instability caused by herdsmen-farmers clashes. OSH has recently been expanded to replace the Southern Kaduna State Operation Harbin Kunama II, which serves a similar purpose to that of the Plateau OSH [54].

\subsubsection{The National Grazing Reserve Bill of 2016 Initiative}

In 2016, the Nigerian legislature sponsored a National Grazing Reserve bill to alleviate herdsmen-farmer tensions. Due to resistance from several stakeholders, the Bill did not pass. They antagonized the Bill based their disapproval on Bill's provisions requirements of the Land Use Act of 1978, vesting in the state governors all responsibilities pertaining to the regulation of ownership, administration, acquisition, 
Journal of Digital Food, Energy \& Water Systems, 2 (2): 33-54, 2021

ISSN 2709-4529

(C) Centre for Cyber Physical Food, Energy \& Water Systems

and management of the lands in Nigerian [55]. Thus, unless modified, the Land Use Act is a National Assembly Act and, by extension, binding law. State administrations and their parliamentary members have traditionally been vehemently opposed to forming grazing reserves under their authority. They see it as an infringement on their constitutionally mandated powers [56].

\subsubsection{Cattle Ranching System Proposal}

In response to rising tensions and mass deaths caused by seasonal pastoral migrations, the government adopted National Livestock Plan in 2018, a 10-year plan to cost the FGN around 179 billion Naira. The initiative would snowball to the development of the 94 Ranch throughout the federation's ten pilot states [57]. Again, state administrations, particularly in the South and North Central regions, opposed the concept, citing that their states do not have as much land as their counterparts in the North [58].

\subsubsection{Prohibition of Open Grazing Legislation}

As part of efforts to address the ongoing conflict between herdsmen and farmers in several regions, state governments have begun enacting legislation restricting open grazing. This, they think, would lessen the possibility of herders destroying farmlands and causing disputes. States, including Benue, Ondo, Oyo, Akwa Ibom, and Taraba are leading the opposition by implementing state laws forbidding open grazing. On May 22, 2017, the state of Benue passed the Open Grazing Prohibition and Ranches Establishment Law (2017), which went into effect on November 1, 2017 [59]. The states of Ekiti and Taraba have also passed legislation restricting open grazing. As a result, open grazing in any form is illegal in many states and punishable by law. The conclusion is that because the security of people and property is the duty of government at all levels, and because the Nigerian Constitution appropriately places land use within the jurisdiction of the states, additional states may accept the open grazing prohibition.

\subsubsection{The Federal Government' Great Green Wall Agency}

In 2013, the federal government established the Great Green Wall Agency to combat desertification. This was in response to the African Union's Great Green Wall Initiative, which began in 2007 and encouraged member countries to plant 8,000 kilometers of trees in the Southern Sahel to combat desertification [60]. The seasonal movement of herders from one location to the next in search of water and greenery for livestock 
Journal of Digital Food, Energy \& Water Systems, 2 (2): 33-54, 2021

ISSN 2709-4529

(C) Centre for Cyber Physical Food, Energy \& Water Systems

grazing is a key factor driving desert expansion in the Sahel as a result of climate change.

\section{The Imperative for Information and Communications Technology towards Food Security and the Resolution of the Farmers-Herdsmen Conflicts}

Nigeria continues to be one of the least secure countries in terms of food production, security, and long-term sustainability. The recurring issue of farmers-herdsmen clashes is at the heart of this uneasiness. Apart from the recurring agricultural conflict between farmers and herdsmen over land possessions, several agriculturally-induced crop production glitches, such as biotic stresses, abiotic stresses, lack of water obtainability, soil toxicity, post-harvest loss, precision prediction inability by the farmers on how and when to farm, absence of information on healthy diets, and others, have all contributed significantly to Nigeria's unpalatable state of food security. Rather than seizing the emerging potential of information and communication technology, appropriate parties, most notably the government, have yet to overhaul the food production system through upgraded technologies. Enhanced technological techniques and practices capable of bringing improved food security in Nigeria are yet to be fully embraced by relevant stakeholders, the farmers, and the herdsmen. Pest-resistant crops and diseases, eggplant that is pest-resistant, pesticides, rust-resistant wheat varieties, spatial repellent for onfarm pests, herbicides, tilling machines, enhanced agronomic practices, salt-tolerant crops (for instance, potato, quinoa), climate-resistant crops, tissue culture and micropropagation, conventional breeding, marker-assisted breeding, cutting-edge genetic engineering, low-cost extension workers, diagnostic toolkit for liquid nitrogen and lowcost alternatives for animal semen conservation, low-cost diagnostic toolkits for livestock veterinarians, tissue engineering for laboratory-grown animal products, lowcost veterinary pharmaceuticals (ideally thermostable), water storage technologies (subsurface water technologies, aquifers, ponds, tanks, low-cost plastic water tanks, natural wetlands, reservoirs), canal irrigation, micro-irrigation technologies, water lifting (solar-power irrigation pumps and hand-powered mechanical pumps, treadle pumps, , hydrogen-powered pumps, electric and fossil fuel pumps), fungal seed and plant treatment for water-related stress, irrigation forecast systems and decision-support systems, planting technology for increased water efficiency, water-buffering technology, rainwater harvesting mechanisms, desalination water technologies, portable sensors for groundwater detection, fruit preservation technologies, thermal battery-powered milk chillers, nanotechnology, improved genetic variations, seed and 
Journal of Digital Food, Energy \& Water Systems, 2 (2): 33-54, 2021

ISSN 2709-4529

(C) Centre for Cyber Physical Food, Energy \& Water Systems

grain drying, storage and aeration know-how, biowax coating system, hexanal formulations, rice parboiling technology, processing efficient technology for pulses, rice-drying technology, grading, cleaning, and packing technology, off-grid refrigeration, low-cost solar dryers, low-cost refrigerated vehicles, vacuum or hermetic sealing, dissemination of nutrition information through health mobile applications or technologies, weather-forecasting technologies, infrared sensors to detect crop stress, hyperspectral imaging, drones based technology and satellites and other innovative technological mechanisms and imperative in food production system that can help guarantee considerable level of food security are mostly non-existent in Nigeria.

Similarly, the lack of technological invention in the quest for a peaceful resolution of the persistent fame-herdsmen conflict has aggravated the conflict. In many cases of farmland infringements by herdsmen, farmers can only recourse to walking several miles to make reports at the police station. The implication is that before the officers arrive at the crime scene, the offender may have scampered away. Rather than relying on the predominant counterproductive practice, a mobile telecommunications application or software could have been designed primarily for the farmers and the herdsmen to make fast and direct complaints of crimes to the police for immediate intervention or investigation.

Furthermore, it is quite disdainful to have found that most farmlands across the Nigerian state do not possess unique recording cameras for safety and security monitoring. While the practice of installing remote recording cameras (CCTV) in most private and public properties in developing countries is rife, Nigeria and other developing countries have not made it a priority to ensure the installation of security cameras in pricey properties such as farmlands and others. The implication is that many dodgy herdsmen may be tempted to commit acts of trespass, violence, and grazing of the cattle of farmers' farmlands in the hopes of not getting caught, especially when there are no security cameras installed on the farmland. Hence, to deter potential aggressors amongst the herdsmen, the installation of security, telecommunications cameras, or CCTV has to be imperative in light of the increasing conflict between the growers and herdsmen.

Again, to date, here in the study area, no official database for the herdsmen across the Nigerian state. Coupled with the influx of herdsmen from all over Africa, especially neighboring West African countries, local herdsmen in Nigeria remain largely unaccounted for and digitally uncaptured. This increases the risk of criminals infiltrating the ranks and files of the herdsmen due to the lack of a digital database that would harbor the personal and professional data of the herdsmen. 
Journal of Digital Food, Energy \& Water Systems, 2 (2): 33-54, 2021

ISSN 2709-4529

(C) Centre for Cyber Physical Food, Energy \& Water Systems

\section{Conclusion}

Food is an essential aspect of a man's life because it helps to support his growth and well-being. The farmers-herders' conflict remains a major food security threat, especially in Nigeria, with a growing population estimated at around 170 million. The findings of this study have shown that conflicts between farmers and herdsmen account for a decline in food production. According to the UN Agriculture Agency [61], notwithstanding, the robust global food supply, flooding, localized drought, and lingering farmer-herdsmen conflicts have excruciated and increased and perpetuated food insecurity in the country. Thus, succeeded in slowing down, retarding, and even stopping some major economic activities in most parts of the country is this menace. The damages to the properties and even loss of lives, the declining and diminution in agricultural produce, unemployment, loss of revenue, etc., have let loose fear, animosity, and hatred among the people and have also increased rural-urban migration, poverty, and social problems. These and many other factors remain Nigeria's topmost challenges to meaningful food security and an enduring peaceful resolution of the farmers-herdsmen conflict. The apparently-visible lack of ICT usage in the quest to find an enduring solution to the farmer-herdsmen conflict that has negatively affected Nigeria's food security objects has also become a key factor as to why the conflict has remained never-ending. The installation of security cameras across farmlands and other public spaces; the official establishment of a digital database for all herdsmen; and the use of crime reporting and emergency call applications and software for both the herdsmen and farmers are some of the many mechanisms recommended in this study for the nominal and enduring resolution of the lingering farmer-herdsmen conflicts for the actualization of the goal of improved food security in Nigeria.

\section{Acknowledgment}

We appreciate the academic generosity extended to us by Professors John Agbonifo in the course of writing the first draft of this paper. We are also grateful to the two anonymous reviewers for their painstaking review of this paper.

\section{References}

[1] Neethirajan, S. \& Kemp, B. (2021). Digital Livestock Farming. Sensing and BioSensing Research, 32. The Netherlands: Elsevier. 
Journal of Digital Food, Energy \& Water Systems, 2 (2): 33-54, 2021

ISSN 2709-4529

(C) Centre for Cyber Physical Food, Energy \& Water Systems

[2] Anter, T. (2011). Who are the people and their Origin?

[3] Omitola, B. Akinrinde, O. O., Omodunbi, O., Adegboye, D. \& Adedire, S. (2021). Cattle Settlement Policy and Nigeria's troubled Federation: Ethno-religious Politics through other means. Law Research Review Quarterly, 7 (3).

[4] Omitola, B., Adedire, S., Akinrinde, O. O., Omodunbi, O. \& Sackflame, M. M. (2021). The Triangle of Terror: Boko Haram, Fulani Herdsmen, Bandits and Organized Insecurity in Nigeria. Studia Securitatis, Vol. 15 (1).

[5] Omitola, B., Adedire, S., Akinrinde, O. O., Omodunbi, O. \& Sackflame, M. M. (2021). The Triangle of Terror: Boko Haram, Fulani Herdsmen, Bandits and Organized Insecurity in Nigeria. Studia Securitatis, Vol. 15 (1).

[6] Adetula, D. (2016). Understanding the Fulani herdsmen crisis in Nigeria: Here is everything you need to know. Accessed from www.venturesafrica.com on 25 February, 2020.

[7] Balogun O. S. (2017). Assuring Food Security: The Role of the Crop Protectionist. The One Hundred and Seventieth Inaugural Lecture, University Press, Ilorin.

[8] Balogun O. S. (2017). Assuring Food Security: The Role of the Crop Protectionist. The One Hundred and Seventieth Inaugural Lecture, University Press, Ilorin.

[9] Balogun O. S. (2017). Assuring Food Security: The Role of the Crop Protectionist. The One Hundred and Seventieth Inaugural Lecture, University Press, Ilorin.

[10] Nyong A. \& Fiki C. (2005). Droughts Related Conflicts, Management and Resolution in the West Africa Sahel. Human Security and Climate Change International Workshop. Oslo, GECHS CICERO, pp5-16.

[11] Yahaya H. N. (2013). Fulani Herdsmen and Local Communities: Ensuring Peaceful Relationship. Kwara State Council of Chiefs Proceedings of the 1st Royal Summit on Peace and Security in Kwara State.

[12] Balogun O. S. (2017). Assuring Food Security: The Role of the Crop Protectionist. The One Hundred and Seventieth Inaugural Lecture, University Press, Ilorin.

[13] Food and Agricultural Organization (2009). State of Food Insecurity in the World. (SOFI) 2009, Rome: Food Agricultural Organization. 
Journal of Digital Food, Energy \& Water Systems, 2 (2): 33-54, 2021

ISSN 2709-4529

(C) Centre for Cyber Physical Food, Energy \& Water Systems

[14] Balogun O. S. (2017). Assuring Food Security: The Role of the Crop Protectionist. The One Hundred and Seventieth Inaugural Lecture, University Press, Ilori

[15] United Nations Agriculture Agency (2017). Conflicts, Drought Drive Hunger Despite Strong Global Food Supply. UN News Centre, Hunger and Food Security News.

[16] United Nations Agriculture Agency (2017). Conflicts, Drought Drive Hunger Despite Strong Global Food Supply. UN News Centre, Hunger and Food Security News.

[17] World Bank (1986). Rising Global demand in Farmland: can it yield Sustainable and Equitable Benefits? The World Bank. Washington DC.

[18] Okechukwu I. E. (2014). Food Security in Nigeria: A Thematic Exposition. Arabian Journal of Business and Management Review, 4 (1).

[19] Okechukwu I. E. (2014). Food Security in Nigeria: A Thematic Exposition. Arabian Journal of Business and Management Review, 4 (1).

[20] United Nations Agriculture Agency (2017). Conflicts, Drought Drive Hunger Despite Strong Global Food Supply. UN News Centre, Hunger and Food Security News.

[21] United Nations Agriculture Agency (2017). Conflicts, Drought Drive Hunger Despite Strong Global Food Supply. UN News Centre, Hunger and Food Security News.

[22] Food and Agricultural Organization. (2004). Rome Declaration and World Food Security plan of Action, Rome: Food and Agricultural Organization.

[23] Balogun O. S. (2017). Assuring Food Security: The Role of the Crop Protectionist. The One Hundred and Seventieth Inaugural Lecture, University Press, Ilorin.

[24] Food and Agricultural Organization (2009). State of Food Insecurity in the World. (SOFI) 2009, Rome: Food Agricultural Organization.

[25] Mikailu N. (2016). Making sense of Nigeria's Fulani-farmer conflict. BBC News Africa Section, 5 May.

[26] Nwosu C. (2017). Between Fulani Herdsmen and Farmers National Security Under Buhari. The Republic. Accessed from: http://www.republic.com.ng/aprilmay-2020/fulani-herdsmen farmers/. 
Journal of Digital Food, Energy \& Water Systems, 2 (2): 33-54, 2021

ISSN 2709-4529

(C) Centre for Cyber Physical Food, Energy \& Water Systems

[27] Aluko, I.O. (2017). Urban Violence Dimension in Nigeria: Farmers and Herders Onslaught. AGATHOS, Volume 8, Issue 1. Accessed from www.agathos-internationalreview.com

[28] Institute of Peace and Conflict Resolution IPCR (2012). Strategic Conflict Assessment: North Central Zone. Kwara State Ministry of Information and Communications.

[29] Adisa, R.S. (2010). Management of farmers-herdsmen conflict in North-central Nigeria: Implication for Collaboration between agricultural extension and service and other stakeholders. Journal of International Agricultural Education and Extension, 18(1), 60- 72 .

[30] Albert, I. O. (2001). Building Peace, advancing Democracy: Experience with Third Party Interventions in Nigeria's Conflict. Johns Archers Publishers Limited: Ibadan.

[31] Albert, I. O. (2001). Building Peace, advancing Democracy: Experience with Third Party Interventions in Nigeria's Conflict. Johns Archers Publishers Limited: Ibadan.

[32] Albert, I. O. (2001). Building Peace, advancing Democracy: Experience with Third Party Interventions in Nigeria's Conflict. Johns Archers Publishers Limited: Ibadan.

[33] Bello, M. (2015). How to Solve the Fulani Herdsmen versus Farmers Clashes in Nigeria by MIYETTI Allah. Premium Times Online Newspaper, 14 October 2015 Available at http://www.premium-times-ng.com.html Accessed 11 March, 2020.

[34] Bello, M. (2015). How to Solve the Fulani Herdsmen versus Farmers Clashes in Nigeria by MIYETTI Allah. Premium Times Online Newspaper, 14 October 2015 Available at http://www.premium-times-ng.com.html Accessed 11 March, 2020.

[35] Albert, I. O. (2001). Building Peace, advancing Democracy: Experience with Third Party Interventions in Nigeria's Conflict. Johns Archers Publishers Limited: Ibadan.

[36] Bello, M. (2015). How to Solve the Fulani Herdsmen versus Farmers Clashes in Nigeria by MIYETTI Allah. Premium Times Online Newspaper, 14 October 2015 Available at http://www.premium-times-ng.com.html Accessed 11 March, 2020.

[37] Food and Agricultural Organization (2009). State of Food Insecurity in the World. (SOFI) 2009, Rome: Food Agricultural Organization.

[38] Mbachu, O. (2008). Foreign Policy Analysis: The Nigerian Perspective. Kaduna: Joys Graphics Publishers, 45-70. 
Journal of Digital Food, Energy \& Water Systems, 2 (2): 33-54, 2021

ISSN 2709-4529

(C) Centre for Cyber Physical Food, Energy \& Water Systems

[39] Nana, T. (2017). Population Demographics and National Development in Nigeria. Paper Presented at the National Defence College Abuja on 26 September 2017 for Participants of Course 26.

[40] Abah, R. C. \& Petja, M. (2015). The Socio-economic Factors affecting Agricultural Development in the Lower River Benue Basin. Journal of Biology, Agriculture and Healthcare, 5 (24).

[41] Omitola, B. Akinrinde, O. O., Omodunbi, O., Adegboye, D. \& Adedire, S. (2021). Cattle Settlement Policy and Nigeria's troubled Federation: Ethno-religious Politics through other means. Law Research Review Quarterly, 7 (3).

[42] Oyetunbi, O., \& Akinrinde, O. O. (2021). Political Crisis and The Politics of Religious Divisiveness in Nigeria's Fourth Republic. The Digest: Journal of Jurisprudence and Legisprudence, 2 (2), 173-196.

[43] Food and Agricultural Organization (2009). State of Food Insecurity in the World. (SOFI) 2009, Rome: Food Agricultural Organization.

[44] [45] Abughdyer R.A. (2016). Farmers and Pastoralists Conflicts in Benue State: Implications for food security. M.Sc Thesis Submitted to the Department of Political Science, Faculty of Social Sciences, Benue State University Makurdi.

[46] Okoli, A. C., \& Atelhe, A. G. (2014). Nomads against natives: A political ecology of herderfarmer conflicts in Nasarawa, Nigeria. American International Journal of Contemporary Research, 4 (2).

[47] [48] Ofem, O. O. \& Iyang, B. (2014). Livelihood and Conflict dimension among crop farmers and Fulani herdsmen in Yakur region of Cross River State. Mediterranean Journal of Social Sciences, 5 (8).

[49] Alli, Y. (2018). Federal Government to build 94 ranches in 10 states. The Nations News, 20 June 2018. http://thenationonlineng.net/fed-govt-to-build-94-ranches-in-10-states/, accessed on 11 March, 2020.

[50] [51] Okoli, A. C., \& Atelhe, A. G. (2014). Nomads against natives: A political ecology of herder-farmer conflicts in Nasarawa, Nigeria. American International Journal of Contemporary Research, 4 (2).

[52] Peace and Security Forum (2017). Resolving the Herders/Farmers Conflict in Nigeria, Policy Brief. 
Journal of Digital Food, Energy \& Water Systems, 2 (2): 33-54, 2021

ISSN 2709-4529

(C) Centre for Cyber Physical Food, Energy \& Water Systems

[53] Federal Government of Nigeria (1999) Constitution of the Federal Republic of Nigeria.

[54] Agande, B. (2017). Army Launches Operation Harbin Kunama II in Southern Kaduna. Vanguard News. Available at: https://www.vanguardngr.com/2017/04/army-launchesoperation-harbin-kunama-ii-southern-kaduna/, accessed 17 February, 2020.

[55] Land Use Decree (1978) No. 6, Cap 202. Laws of the Federation of Nigeria.

[56] Abughdyer R.A. (2016). Farmers and Pastoralists Conflicts in Benue State: Implications for food security. M.Sc Thesis Submitted to the Department of Political Science, Faculty of Social Sciences, Benue State University Makurdi.

[57] [58] Alli, Y. (2018). Federal Government to build 94 ranches in 10 states. The Nations News, 20 June 2018. http://thenationonlineng.net/fed-govt-to-build-94-ranches-in-10-states/, accessed on 11 March, 2020.

[59] Alli, Y. (2018). Abughdyer R.A. (2016). Farmers and Pastoralists Conflicts in Benue State: Implications for food security. M.Sc Thesis Submitted to the Department of Political Science, Faculty of Social Sciences, Benue State University Makurdi.

[60] Abughdyer R.A. (2016). Farmers and Pastoralists Conflicts in Benue State: Implications for food security. M.Sc Thesis Submitted to the Department of Political Science, Faculty of Social Sciences, Benue State University Makurdi.

[61] Abughdyer R.A. (2016). Farmers and Pastoralists Conflicts in Benue State: Implications for food security. M.Sc Thesis Submitted to the Department of Political Science, Faculty of Social Sciences, Benue State University Makurdi.

\section{Authors}

Olawale Olufemi AKINRINDE is Lecturer II at the Department of Political Sciences, Osun State University, Nigeria. Having published extensively, Olawale's works have appeared in Journal of African-centred Solutions in Peace and Security, Acta Political Polonica, Studia Securitatis, Political Review, European Journal of Geopolitics, among others.

Abdullahi Abdulazeez OSUWA is Lecturer II at the Department of Political Science, Kogi State University, Nigeria. His works have appeared in journals such as Political Review, Studia Politica Slovaca, amongst many. 
Journal of Digital Food, Energy \& Water Systems, 2 (2): 33-54, 2021

ISSN 2709-4529

(C) Centre for Cyber Physical Food, Energy \& Water Systems

Kayode Wakili OLAWOYIN is Lecturer II at the Department of Political Science, Osun State University, Nigeria. He holds a PhD in Local Government Studies from Obafemi Awolowo University, Nigeria.

Dauda Ayodele MORAKINYO is a Lecturer in the Department of Business Administration, Osun State University, Nigeria. 